\title{
Új Tortricidae fajok a Dél-Dunántúlon (Lepidoptera)
}

\author{
FAZEKAS IMRE
}

\author{
Pannon Intézet, 7625 Pécs, Magaslati út 24., Hungary \\ e-mail: fazekas@microlepidoptera.hu
}

\begin{abstract}
FAZEKAS I.: New Tortricidae species in South-Transdanubia, SW Hungary (Lepidoptera).
Abstract: The region of South Transdanubia covers the south-western part of Hungary, a territory bordered by the Danube and Drava Rivers and the Lake Balaton. In the South-Transdanubia region the sub Mediterranean climate is most characteristic in the hilly area (150-682 m).

The author revise the Tortricidae material housed in natural history collections in Hungary. Four species were identified as new records for the South Transdanubia: Cochylimorpha woliniana (Schleich, 1868); Cochylidia rupicola (Curtis, 1834); Cochylidia moguntiana (Rössler, 1864); Xerocnephasia rigana (Sodoffsky, 1829). The species are very locally and rare in Hungary. Several habitats have been destroyed or transformed so the species are endangered. Cochylimorpha woliniana flight begins early in May. Cochylidia rupicola only known in 8-10 localities on various habitats. We know little on Cochylidia moguntiana species. It has been collected from the beginning of the 20th century. One of the most interesting species of research is Xerocnephasia rigana. So far, little knowledge of the distribution and bionomy of the species have been reported. Most of the collecting sites are in the hills and mountain ranges but its occurrences are only sporadic in plains. The author has recently collected Xerocnephasia rigana in the southernmost mountainous region of Hungary, the Villány hills. The species mostly prefers the following habitats: rocky slopes, steppes, karst shrubby woodlands, dry shrubs, sandy grasslands and forest edges. The flying period takes from late April to late July, probably in two generations. The study describes in detail the life history of the four species and voucher specimen's geographical distribution is depicted on maps. With 13 figures.
\end{abstract}

Keywords: Lepidoptera, Tortricidae, first record, faunistic, biology, distribution, Hungary

\section{Bevezetés}

Magyarországon eddig 478 sodrómoly faj előfordulása bizonyított (PASTORÁLIS et al. 2016), de további taxonok kimutatása várható, különösen a problematikus fajcsoportok, fajpárok genitália- vagy DNA vizsgálata után (krypto-fajok). Magyar faunakutatás még mindig nélkülözi a hazai Tortricidae monográfiát, amely összefoglalja a fajok bionómiáját, földrajzi elterjedését. Ennek egyik oka, hogy a Fauna Hungariae füzetsorozatban a Tortricidae kötet nem készült el.

Az elmúlt évtizedekben több Tortiricidaekkel foglalkozó tanulmányomban számos magyarországi faj taxonómiájával, bionómiájával és földrajzi elterjedésével foglalkoztam (FAZEKAS 1991ab, 1992ab, 1994ab, 1995ab, 2007ab, 2008 stb.), amelynek célja a magyar Tortricidae fajok elterjedési atlaszának előkészítése és összeállítása. Jelen munkámban négy fajt mutatok be, amelyeknek korábban ismeretlenek voltak a DélDunántúlon vagy előfordulásuk a bizonyító példányok hiánya miatt kétséges volt. 


\section{Anyag és módszer}

Vizsgálataim módszertanát korábbi munkáimban részletesen leírtam (vö. FAZEKAS 1994, 2008). Újabban a hagyományos genitália vizsgálatokat, az imágók fényképezését, a térképek készítését kibővítettem (FAZEKAs 2017). Azért, hogy az ivarszervek térszerkezetét a későbbiekben is tanulmányozni lehessen, a vizsgálati anyag példányainak genitáliáját 97\%-os glicerinben tartósítva, szilikon csőben, a rovartüre tüztem. Több problematikus fajról, fajpárról tartós, euparal preparátum készült.

Az imágók képei Sony DSC-H100v fényképezőgéppel és Zeiss sztereo mikroszkópra szerelt BMS tCam 3,0 MP digitális kamerával készültek, a ScopePhoto 3.0.12 szoftver segítségével. A genitália fotókat a Scopium XSP-151-T-Led biológia mikroszkóppal és a számítógéphez csatlakoztatott MicroQ 3.0 MP digitális kamerával készítettem 20x-os és 50x-es nagyítással. Az így elkészített habitus és preparátum fotókat a Corel Draw/ Paint és Photoshop programokkal elemeztem. A térképezés során többféle adatgyüjtést végeztem: geokoordinátás (= ponttérképezés), folt-térképezés, földrajzi(hely) nevek szerint. Az igen heterogén adatsorok alapján készítettem el a fajok magyarországi lelöhelytérképét. Az összes példány adatsora a Pannon Intézetben vezetett magyarországi Tortricidae fauna elektronikus ,,adatbankjába” van dokumentálva. A tanulmányban tárgyalt fajok bizonyító példányai a Magyar Természettudományi Múzeumban (Budapest), a Pannon Intézetben (Pécs) illetve Buschmann Ferenc (Jászberény) gyüjteményében vannak elhelyezve. A bizonytalan identifikáción alapuló irodalmi közléseket a fajok elterjedésénél nem vettem figyelembe.

\section{Eredmények}

\section{Cochylimorpha woliniana (Schleich, 1868)}

Irodalom: FAzeKas 1993, NuPPONEN et al. 2001, Petrich 2001, RazowsKi 2001, 2009, SZABÓKY 1982.

Bionómia: RAzowski (2009) szerint a Palearktikumban az imágók júniustól augusztus közepéig repülnek. Magyarországon május eleji példányok is előkerültek. A májusi repülés a palearktikus irodalomban még nem ismert. A hernyók augusztustól - áttelelés után - Artemisia absinthium-on élnek.

Habitat: száraz rétek, ugarok, legelők, ruderália-gyepek; általában homokos talajon, de szórványosan mészköves, vulkanikus sziklagyepekben és lejtősztyepeken is.

Magyarországi elterjedés: Eddig csupán a Balaton és a Velencei-tó térségében ismert igen lokális populációja: Kis-Balaton (Zalavári-erdő), Tihany, Csopak, Agárd.

Area: Főként Dél- és Közép-Európából ismert, igen lokálisan; európai faunaelem (RAZOWSKI 2009). NuPPONEN et al. (2001) vizsgálatai alapján azonban a faj Európától egészen Mongóliáig előkerült. Ennek alapján erősen vitatható Razowski európai faunaelem besorolása, minden bizonnyal egy szibériai faunaelem.

Jegyzet: A faj populációinak elterjedése, bionómiája a teljes Pannon életföldrajzi régióban felülvizsgálatot igényel. Mivel a most feltárt élőhelyek túlnyomóan a Balaton-felvidéki Nemzeti Park területére esnek fontos volna egy monitoring vizsgálat elindítása.

Cochylidia rupicola (Curtis, 1834)

Irodalom: Buschmann 2012, RAzowski 2001, 2001, 2009, SzabóKy 1994, 1999.

Bionómia: az imágók június-július hónapokban repülnek; a hernyók Eupathorium cannabium-on, Galatella linosyris-en és Lycopus europaeus-on élnek. 


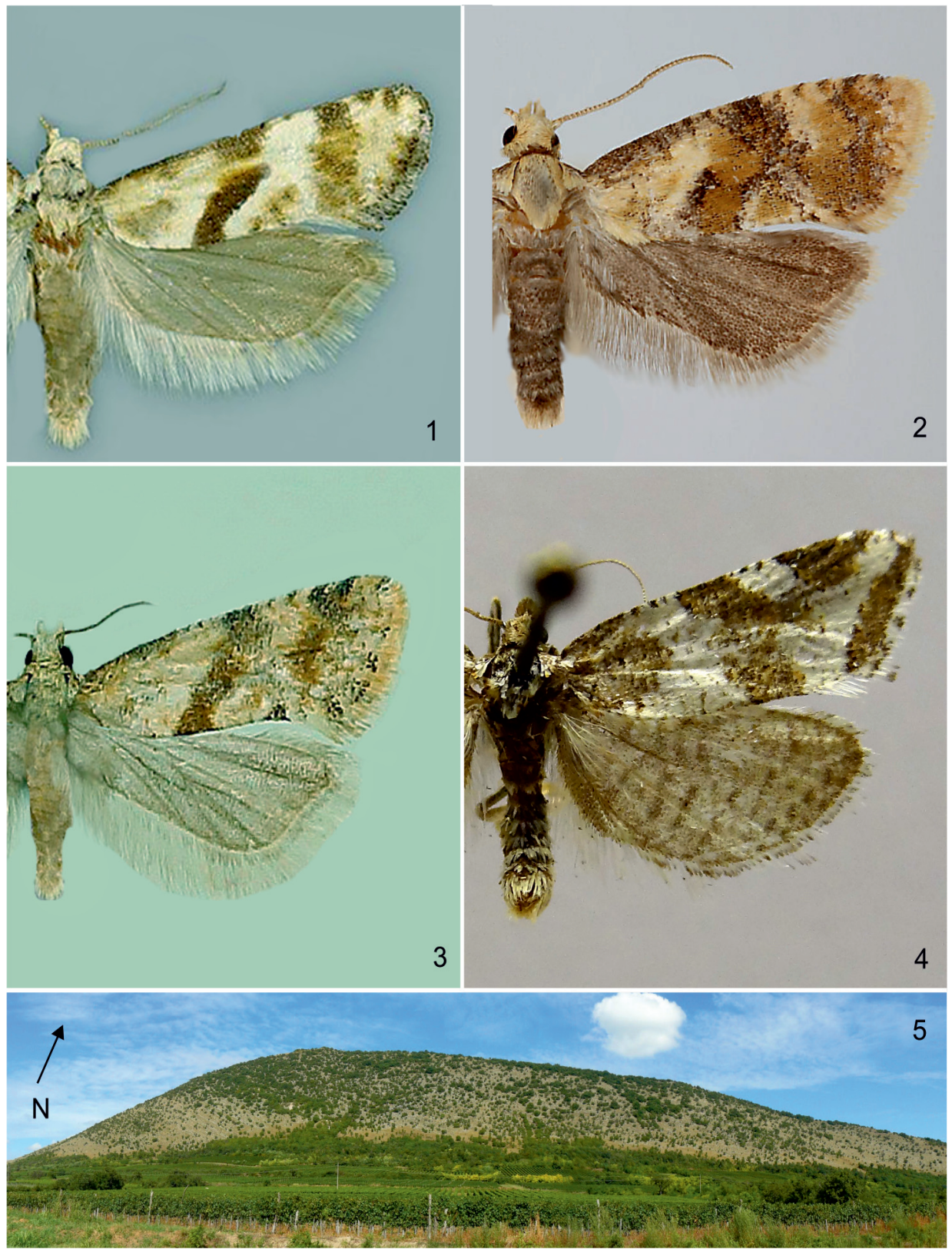

1-5. ábra: 1. Cochylimorpha woliniana (Schleich, 1868); 2. Cochylidia rupicola (Curtis, 1834);

3. Cochylidia moguntiana (Rössler, 1864); 4. Xerocnephasia rigana (Sodoffsky, 1829) imágók;

5. a Xerocnephasia rigana habitatja a Villányi-hegységben (Nagyharsány, Szársomlyó) 


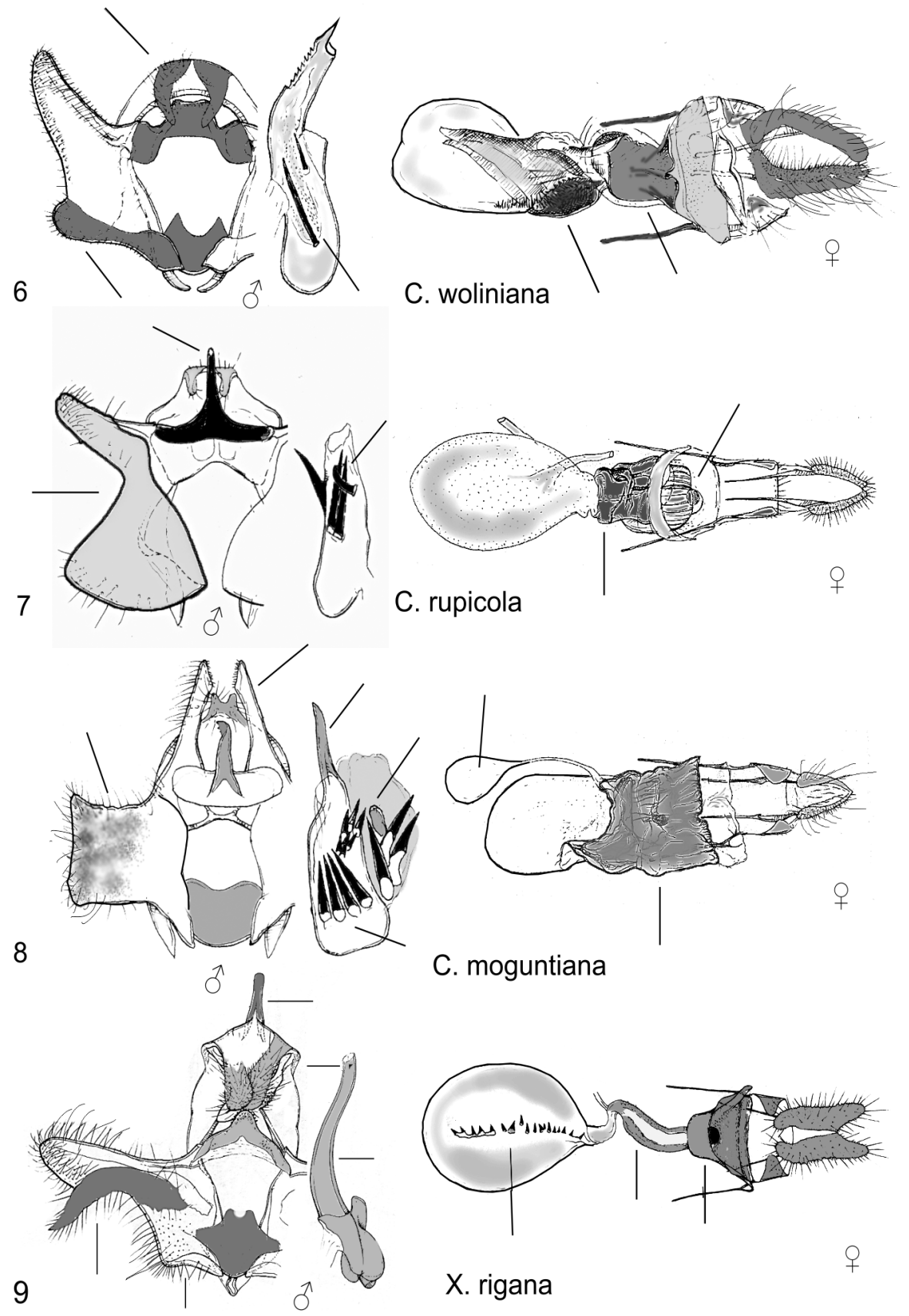

6-9. ábra: Hím és nőstény genitáliák. 6. Cochylimorpha woliniana (Schleich, 1868);

7. Cochylidia rupicola (Curtis, 1834); 8. Cochylidia moguntiana (Rössler, 1864);

9. Xerocnephasia rigana (Sodoffsky, 1829) 
Habitat: euriök faj; ligeterdők szegélye, magaskórósok, rétek, gyomtársulások, patak és árokpartok mentén, sziklagyepek, sztyeprétek. Homokos, mészköves és vulkanikus talajokon egyaránt elöfordul.

Magyarországi elterjedés: A Dél-Dunántúlon csupán Kaposvárott (1951-1968, leg. Pazsiczky S. et Nattán M.) és Simontornyán (1920, leg. Pillich F.) fogták. A Dunántúliközéphegységben a Vértesből (SzABóKY 1994) közölték. A budapesti példányok 1896 és az 1913 közötti időszakból származnak (leg. Uhrik-Mészáros T.), azóta nincs tudomásunk újabb gyüjtési eredményekről. Az Északi-középhegységből csak Szécsényből (1951, leg. Lipthay B.), a gyöngyösi Sár-hegyről (2006, leg. Buschmann F.) és az Aggteleki-karsztról (SzABóKY 1999) került elő. Az Alföldön a kenderesi fénycsapda fogta (1960); újabban pedig BuschmANN (2012) megtalálta Jászfelsőszentgyörgyön és Szentmártonkátán.

Area: Kis-Ázsiától a Balkánon és Oroszország európai részén át egészen DélSkandináviáig, nyugaton a Brit-szigetekig, délen Olaszországig elterjedt.

Jegyzet: Országosan igen lokális és ritka; többnyire régi gyüjtési adatok ismertek, kevés az új megfigyelés. Fenotípusa igen változékony; a kopott példányok azonosítása csak genitália vizsgálattal lehetséges.

\section{Cochylidia moguntiana (Rössler, 1864)}

Irodalom: Buschmann 2012, FAzEKas 1992, 1994, 2002, 2007, Gozmány \& SzabóKY 1986: Horváth 1993, PAsztorális \& SzEőKe 2018, Razowski 2001, 2001, 2009.

Bionómia: a hernyók az Artemisia campestris szárában élnek. Az imágók áprilistól júniusig, illetve júliustól augusztusig két nemzedékben repülnek.

Habitat: föként a homokos területeket preferálja, de előfordul száraz réteken, dolomitos-, mészköves és vulkanikus sziklagyepekben söt karszterdökben is.

Magyarországi elterjedés: hazánkban a legtöbb lelöhelye a Duna-Tisza közén és a Dunántúlon ismert; Villányi-hegység, Mecsek, Kaposvár, Szentpéterfölde Tihany, Németbánya, Fenyőfö, Győr-Bácsa, Vértes, Budai-hegyvidék, Bugac, Csévharaszt, Kecskemét. Igen lokális és ritka faj.

Area: Kínától Szibérián, Afganisztánon át Európáig ismert, ahol nagy földrajzi területeken diszjunkt (FAzEKAS 1994b). Areatípusa szubtranszeurázsiai polidiszjunkt (Fazekas 1994b).

Jegyzet: A faj dél-dunántúli előfordulása a bizonyítópéldány hiánya miatt eddig kétséges volt (vö. FAZEKAS 1994, 2002, 2007). A gyüjteményi revíziók során előkerült egyetlen mecseki példánya (Pécs, Főiskola, 1957.V.15., leg. Balogh I., in coll. MTM) továbbá két kaposvári példány is (Kaposvár, [1]925.V.9. et [1]949.IV.25., leg. Pazsiczky S., in coll. MTM); illetve magam is gyüjtöttem a nagyharsányi Szársomlyón (2000.IV.26., in coll. Pannon Intézet, Pécs).

\section{Xerocnephasia rigana (Sodoffsky, 1829)}

Irodalom: Buschmann 2003, FAzeKas 1993, 2002, Pastorális \& SzeöKe 2018, Pável \& UHryk 1896, Petrich 2001, RAZOWSKi 2002, SzABÓKy 2009.

Bionómia: RAzowsKi (2001) szerint a faj Közép-Európában két nemzedékes: IV-VI; VII-VIII. (IX). Magyarországon a gyüjteményekben csak áprilistól júliusig gyüjtött példányok vannak. Tápnövények: Clematis recta, Pulsatilla- és Anemone fajok.

Habitat: sziklagyepek, lejtősztyepek, karsztbokorerdők, száraz cserjések, homoki erdőssztyep komplexek, erdőszegélyek.

Magyarországi elterjedés: Duna-Tisza köze, Velencei-hegység, Balaton-felvidék (Tihanyi-félsziget, Pécsely), Bakonyalja (Fenyőfö), Vértes, Budai-hegység, Visegrádihegység, Bükk. Mindenütt lokális és igen ritka. A Budapest környéki példányokat 1896 


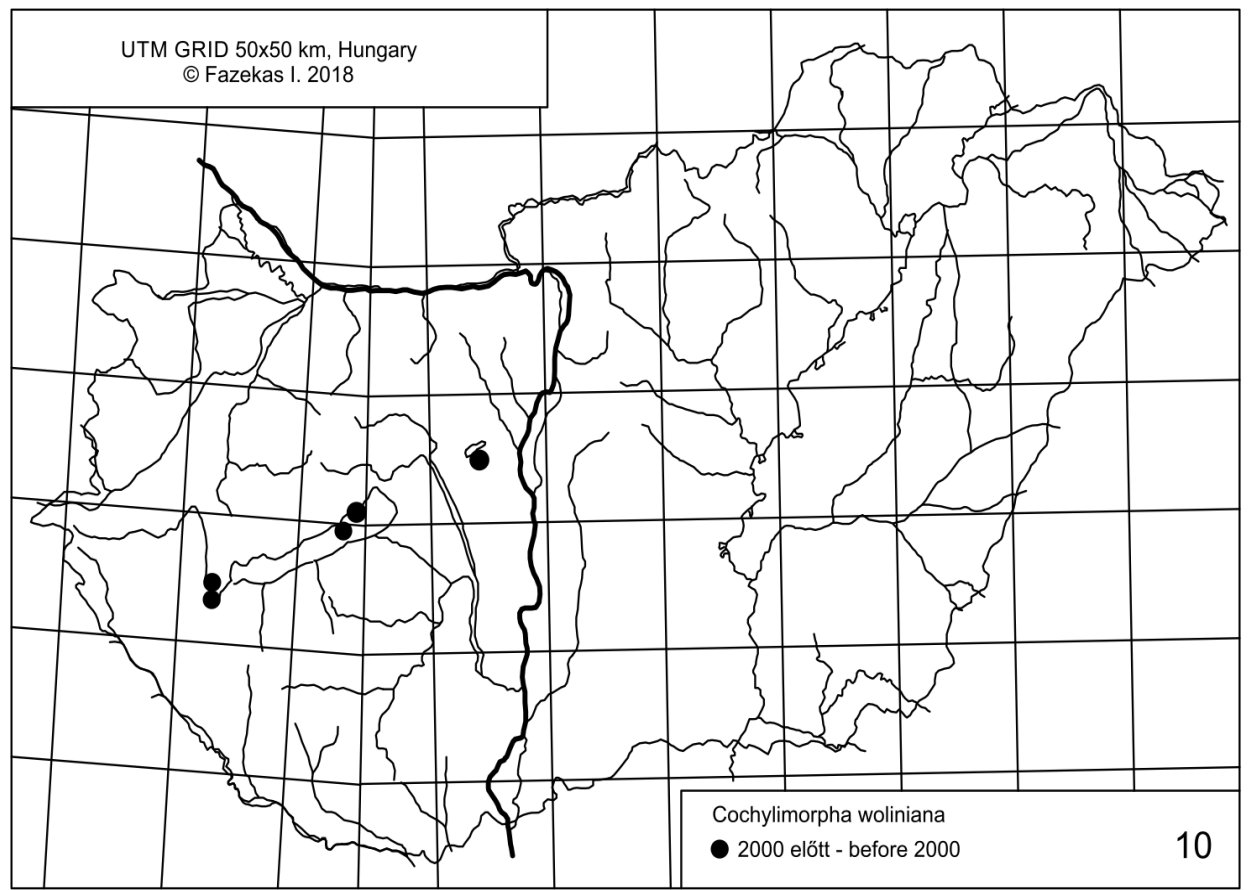

10. ábra: A Cochylimorpha woliniana (Schleich, 1868) elterjedése Magyarországon

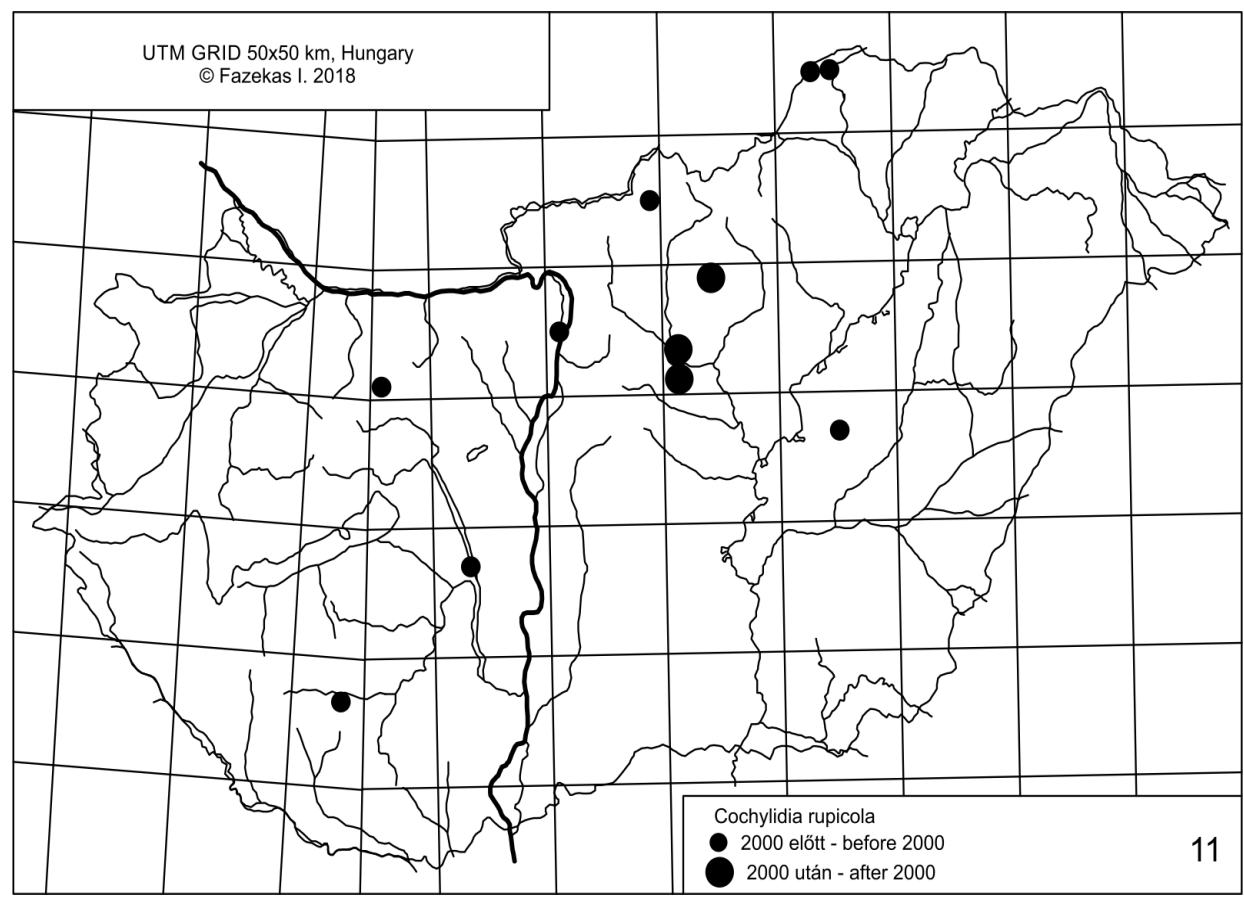

11. ábra: A Cochylidia rupicola (Curtis, 1834) elterjedése Magyarországon 


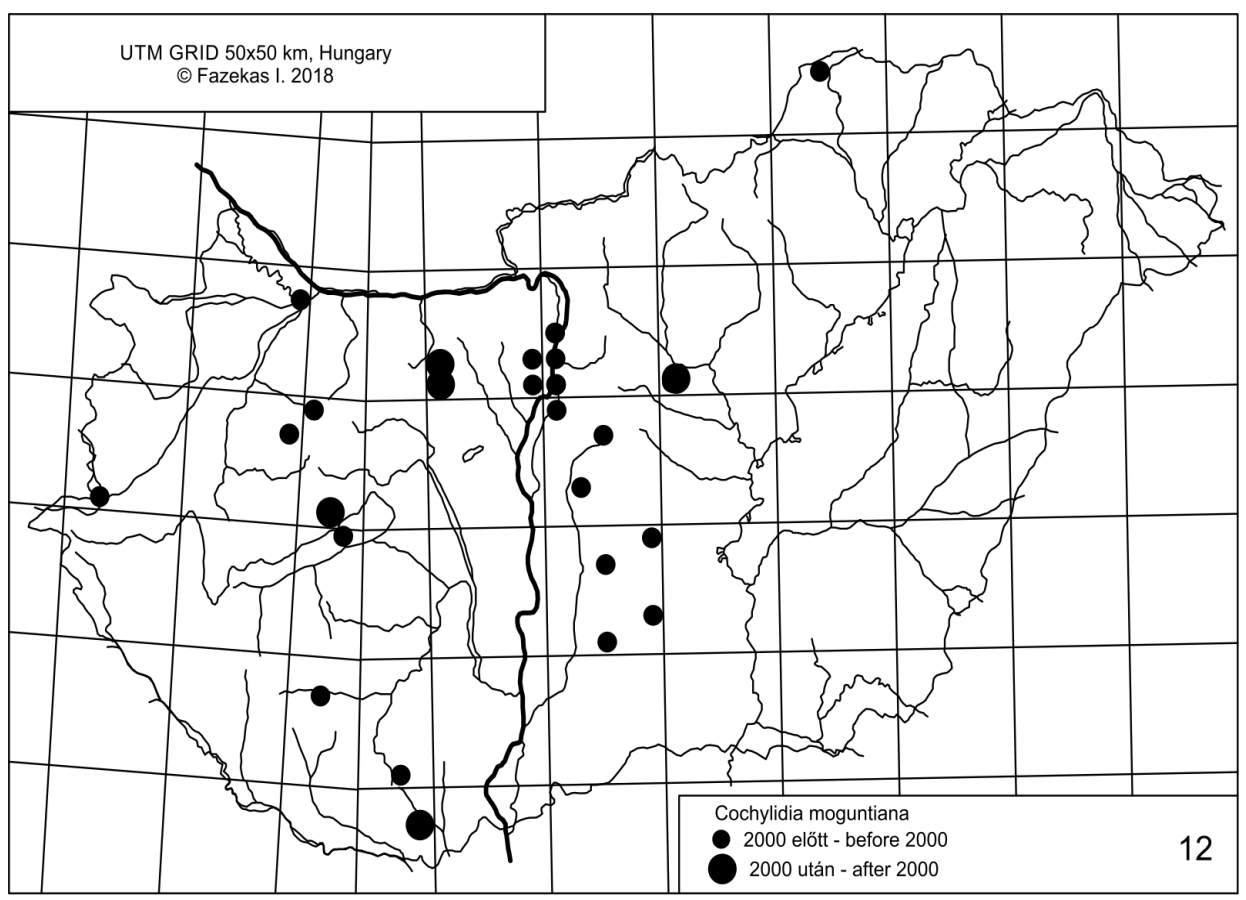

12. ábra: A Cochylidia moguntiana (Rössler, 1864) elterjedése Magyarországon

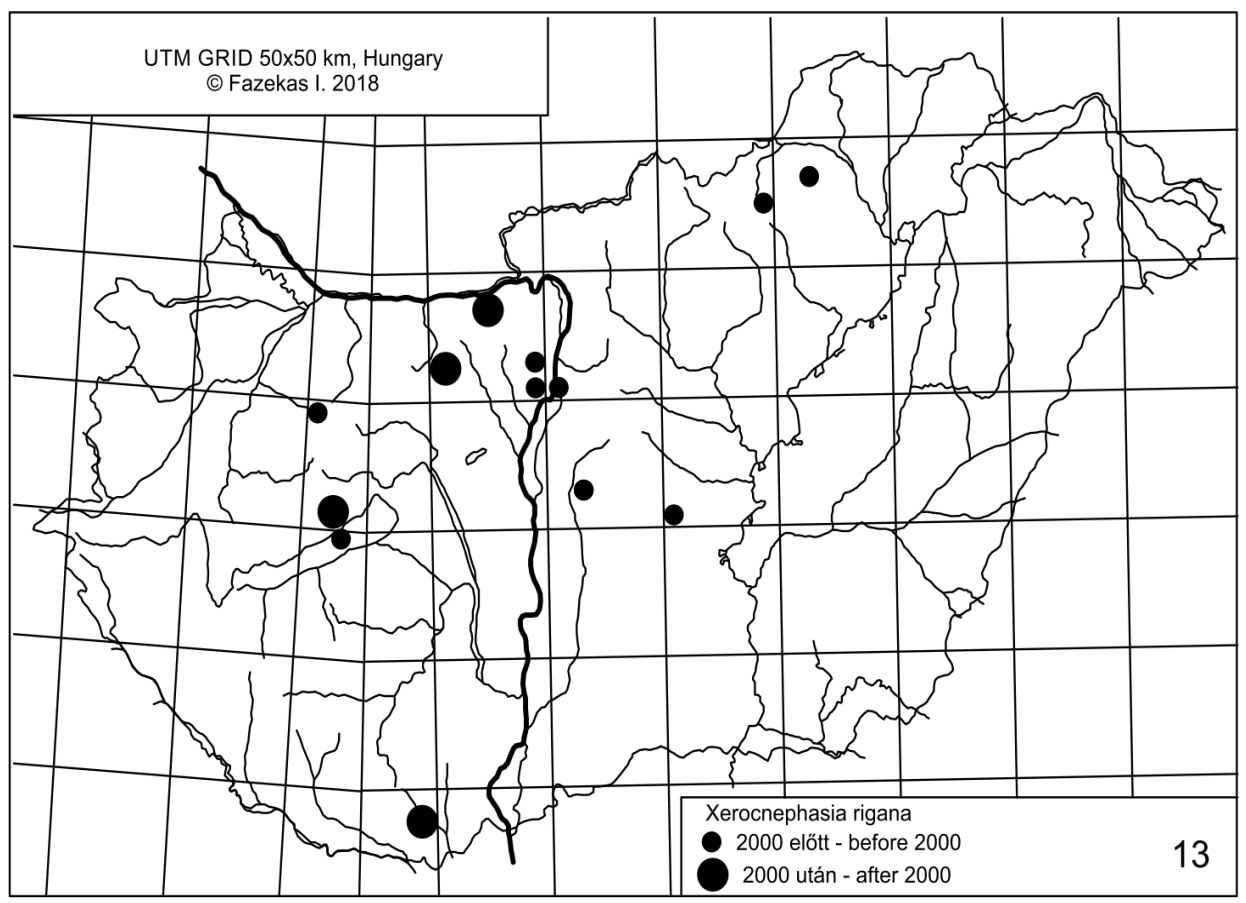

13. ábra: A Xerocnephasia rigana (Sodoffsky, 1829) elterjedése Magyarországon 
és 1953; Duna-Tisza közén pedig 1929 és 1941 között gyüjtötték (in coll. MTM), azóta újabb példányok nem kerültek elő. Legújabb lelőhelye 2013-ból származik (Esztergom, Strázsa-hegy, leg. Buschmann F.). A Dél-Dunántúlon korábban ismeretlen volt (vö. FAZEKAS 2002). Új adata: 1 đ̊, 1 q, Nagyharsány, Szársomlyó, 2000. IV. 26. leg. Fazekas I. (in coll. Pannon Intézet, Pécs). A Cleistogeni-Festucetum rupicolae sztyeprét társulásból azóta újabb bizonyító példányok nincsenek.

Area: Koreától Észak-Kínán és Szibérián át egészen a Brit-szigetekig elterjedt (Razowski 2002). Többnyire diszjunkt faj.

Jegyzet: A Xerocnephasia rigana feltehetöleg Magyarországon veszélyeztetett faj. A XX. század első feléből megismert élőhelyek jelentős része megsemmisült (Budapest környéke). Bionómiájának kutatása föként a természetvédelmi területeken aktuális (pl. Villányi-hegység, Tihanyi-félsziget, Vértes, Velencei-hegység, Bükk stb.). A hazai populációk között földrajzi távolság jelentős, az izoláció következtében a génkicserődés nem biztosított.

\section{Összefoglalás}

A magyarországi Tortricidae fajok bionómiája és földrajzi elterjedése csak hiányosan ismert. A tanulmány megállapítja, hogy a Cochylimorpha woliniana (Schleich, 1868); a Cochylidia rupicola (Curtis, 1834); a Cochylidia moguntiana (Rössler, 1864); a Xerocnephasia rigana (Sodoffsky, 1829) fajok előfordulása bizonyított a Dél-Dunántúlon, $\mathrm{s}$ az előzetes elterjedési térképek bemutatják a taxonok magyarországi lelőhelyeit. A vizsgált fajok hazai populációi lokálisak, az egyedszámok alacsonyak, s feltehetőleg veszélyeztettek, sőt több földrajzi térségben jelenlétük már nem észlelhető. Indokolt, hogy a területileg illetékes nemzeti parkok mielőbb monitoring vizsgálatokat indítsanak el.

\section{Köszönetnyilvánítás}

Köszönöm Buschmann Ferencnek (Jászberény) Bálint Zsoltnak (Budapest) a tanulmány elkészítéséhez nyújtott segítségüket. 


\section{Irodalom - References}

Buschmann F. 2004: A Mátra Múzeum molylepke-gyüjteménye II. Limacodidae - Tortricidae. - Folia Historico Naturalia Musei Matraensis 28: 219-242.

Buschmann F. 2012: A Tápió-vidék lepkefaunája (Lepidoptera). - Rosalia 7: 385-500.

FazeKas I. 1986: A Mecsek hegység faunájára új és ritka lepkefajok (2.). Lepidoptera: Coleophoridae, Yponomeutidae, Tortricoidea, Pyralidae, Pterophoridae | Für die Fauna des Mecsek-Gebirges (SüdUngarn) neue und seltene Schmetterlingsarten, 2. - Folia Comloensis 2: 97-128.

FAZEKAS I. 1991a: Phtheochroa annae Huemer, 1990 und Agriphila brioniella Zerny als neue Arten im BakonyGebirge. - Folia Musei Historico-naturalis Bakonyiensis 10: 59-66.

FAzeKas I. (1991b): Cochylis flaviciliana Westwood 1854 und Stenoptilia plagiodactyla Stainton 1851 als neue Arten für Ungarns Fauna. - Nachrichten des Entomologischen Vereins Apollo, Frankfurt am Main, N.F. 12: 203-210.

FAZEKas I. 1992a: Records of the Cochylini from Hungary, Rumania and Bulgaria based on I. Balogh's Collection (Tortricidae). - Folia Entomologica Hungarica 53: 45-50.

FazeKas I. 1992b: A Thyris fenestrella Sc. valamint közelrokon Cochylini és Crambinae taxonok elemzése az Alpokalján | Eine analyse der Art Thyris fenestrella Sc. sowie der nahe verwandten Cochylini und Crambinae taxa aus den Alpenvorlande, W-Ungarn. - Savaria 20/2: 55-64.

FAZEKAS I. 1993: A Tihanyi Tájvédelmi Körzet lepkefaunája (1.). Faunisztikai alapvetés (Lepidoptera). - Folia Musei Historico-naturalis Bakonyiensis 12: 105-144.

FAZEKAS I. 1994a: Das Cochylini-Material aus Ungarn des Wiener Naturhistorischen Museums und der Zoologischen Staatssammlung München. - Nachrichtenblatt der Bayerischen Entomologen 43: 39-46

FAZEKAS I. 1994b: A magyarországi makrorégiók Cochylini faunája, I. A Dunántúli-dombság | The Cochylini (Lepidoptera: Tortricidae) Fauna of the Hungarian geographical regions I. The Transdanubian Hills. Állattani Közlemények 80: 33-54.

FAZEKAS I. 1995a: Systematisches und synonymisches Verzeichnis der Cochylini Ungarns (Tortricidae). Nachrichten des Entomologischen Vereins Apollo, Frankfurt am Main, N.F. 16: 29-26.

FAZEKAS I. 1995b: A Mecsekvidék és a Völgység sodrómolylepke faunája (Tortricidae) | Die Wickler-Fauna der Mecsek und Völgység-Gegend, S-Ungarn, Tortricidae. - Folia Comloensis 6: 5-33.

FAZEKAs I. 1998: Megjegyzések a Phalonidia gilvicomana Z. és a Crambus hamellus Thnb. magyarországi ismeretéhez | Remarks to the knowledge of Phalonidia gilvicomana Z. and Crambus hamellus Thnb. in Hungary). - Folia Entomologica Hungarica 59: 309-310.

FAZEKAS I. 2001: Somogy megye molylepke faunája (Lepidoptera: Microlepidoptera). - Natura Somogyiensis 1: 303-327.

FAZEKas I. 2002: Baranya megye Microlepidoptera faunájának katalógusa | Catalogue of Microlepidoptera fauna from Baranya county (South-Hungary). - Folia Comloensis 11: 5-76.

FazeKas I. 2007a: Tosirips magyarus Razowski, 1978 in Central Europe (Lepidoptera: Tortricidae). - Natura Somogyiensis 10: 209-212.

FAZEKAS I. 2007b: Microlepidoptera Pannoniae meridionalis, VI. A Mecsek Microlepidoptera katalógusa | Catalogue of Microlepidoptera from Mecsek Mountains, SW Hungary (Lepidoptera). - Acta Naturalia Pannonica 2: 9-66.

FAZEKAS I. 2008: The species of the genus Aethes Billberg, 1821 of Hungary (Lepidoptera: Tortricidae). Natura Somogyensis 12: 133-168.

GozmÁnY L. \& SzABóKy Cs. 1986: Microlepidoptera | In The fauna of the Kiskunság National Park. Budapest, pp. 247-298.

Horváth Gy. 1993: Adatok a Szigetköz lepkefaunájának ismeretéhez (Lepidoptera) | Data tot he knowledge of the Lepidopterous fauna of Szigetköz. - Folia Entomologica Hungarica 54: 170-185.

Nupponen K., Junnilainen J., Nupponen T. \& Olschwang V. 2001: The cochylid fauna of the Southern Ural Mountains, with description of Cochylimorpha ignicolorana Junnilainen \& K. Nupponen sp. $n$. (Lepidoptera: Tortricidae: Cochylini). - Entomologica Fennica 12: 94-107.

Pastorális G. Buschmann F. \& Ronkay L. 2016: Magyarország lepkéinek névjegyzéke | Checklist of the Hungarian Lepidoptera. - e-Acta Naturalia Pannonica 12: 1-258.

PAstorális G. \& SzeőKe K. 2018: A Vértes hegység lepkefaunája | Lepidoptera fauna of Vértes Mountains (Hungary). - e-Acta Naturalia Pannonica 17: 1-73.

PÁvel J. \& Uhryk F. 1896: Microlepidoptera. In Fauna Regni Hungariae III. Arthropoda, Budapest, pp. 53-78. Petrich K. 2001: A Velencei (sic!) táj lepkevilága. - Mezőgazdasági Szaktudás Kiadó, Budapest, 305 p. RAZOWSKI J. 2001: Die Tortriciden (Lepidoptera, Tortricidae) Mitteleuropas. - František Slamka, Bratislava, 319 p. 
RAzOWSKI J. 2002: Tortricidae (Lepidoptera) of Europe | Volume 1 | Tortricinae and Chlidanotinae. - František Slamka, Bratislava, $247 \mathrm{p}$.

Razowski J. 2009: Tortricidae (Lepidoptera) of the Palaearctic Region | Volume 2 | Cochylini. - Fratišek Slamka, Kraków - Bratislava, 195 p.

SzABóKy Cs. 1982: A Bakony molylepkéi | Die Microlepidoptera des Bakony-Gebirges, Ungarn. - A Bakony Természettudományi Kutatásának Erdeményei 15: 1-42.

SzABóKy Cs. 1999: Microlepidoptera of the Aggtelek National Park. In Mahunka S. \& Zombori L.: The Fauna of the Aggtelek National Park. - Budapest, pp. 395-442.

SzAвóKy Cs. 2009: Pécsely lepkéi (Lepidoptera). - Folia Musei Historico-naturalis Bakonyiensis 26: 111-140. 